\title{
A Study of Information Systems in Human Resource Management (HRM)
}

\author{
K P Tripathi \\ Assistant Professor (MCA Programme) \\ Bharati Vidyapeeth Deemed University \\ Institute of Management, Kolhapur, India
}

\begin{abstract}
In today's organizations Human Resource is considered as one of the key resources of business organizations. The transaction processing layer of MIS in human resource function deals with routine activities like attendance recording and payroll calculations. The operational level activities also include maintaining the employee records which is used as a basis for strategic layers. With the growing importance of human resource management and increasing size of the organizations, maintenance of employee related data and generating appropriate reports are the crucial aspects of any organization. Therefore more and more organizations are adopting computer based human resource management systems (HRMS). This paper is an attempt to highlights the role of information systems in Human Resource Management and show how it helps in taking management decisions related to management function especially for the top management.
\end{abstract}

\section{Keywords}

Management Information System, Decision Making, Transaction Processing Unit, MIS Model.

\section{INTRODUCTION}

The Management Information System is a collection of men, tools, procedures and software to perform various business tasks at various levels in the organization. Many organizations have separate MIS departments which are involved in maintaining records, performing transactions, report generations and consolidation of the important information which will be supplied to the various levels of the management. MIS has three basic levels: operational, middle management and top management where the information is passed from bottom to top. This paper is an attempt to design an information system for Birla Corporation Limited, which involves Attendance Capturing \& Recording System which will be used in monitoring the staff, control over the irregularities and reporting to the top management and show how it is useful in decision making at top level. [11]

\section{OBJECTIVE}

The researcher has proposed the study on 'A Study of Information Systems in Human Resource Management (HRM)' with respect to Birla Corporation Limited. The selected organization is of a large scale in terms of size, area and manpower requirement. After preliminary study it was felt to develop an information system for various functionalities specifically maintaining attendance by computerized methods and generating reports for top level management and middle level management.

\section{RELATED WORK}

T. Lucey in the book entitled 'Management Information Systems' defines MIS as a system to convert data from internal and external sources into information and to communicate that information is an appropriate form to managers at all levels in all functions to enable them to make timely and effective decisions for planning, directing and controlling the activities for which they are responsible [5]. Barry E. Cushing in the book entitled 'Accounting Information Systems and Business Organizations' suggests the definition of MIS as a set of human and capital resources within an organization which is responsible for the collection and processing of data to produce information which is useful to all levels of management in planning and controlling the activities of the organization [5]. The Management Information System (MIS) has evolved as an important tool and technique in business management area in the current opportunities and business threats. Right information at right time in right format will decide the managements' Human resource decisions. MIS is one of the important functions of management. In the $21^{\text {st }}$ century the organizations need the information which is accurate, timely and reliable. The MIS plays an important role in providing the information required for crucial decision making which affects directly to the performance of the organization. [8] [11]

\section{CONCEPT AND MEANING OF MIS}

The initial concept of MIS was to process data from the organization and presents it in the form of reports at regular intervals. The system was largely capable of handling the data from collection to processing. It was more impersonal, requiring each individual to pick and choose the processed data and use it for his requirements. The MIS differs since the people in two organizations involved in the same business. The MIS is for the people in the organization. The MIS model may be the same but it differs greatly in the contents. 


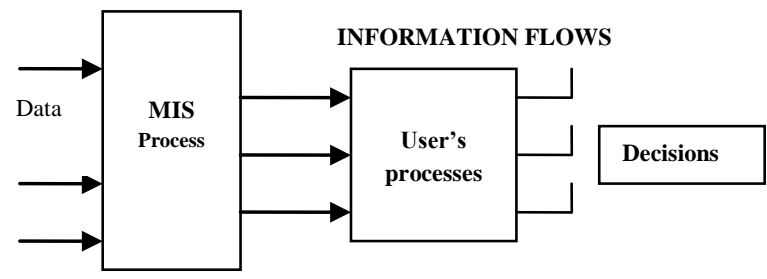

Fig. 1: MIS and Decision Making Process

The MIS, therefore, is a dynamic concept subject to change, time and again, with a change in the business management process. It continuously interacts with the internal and the external environment of the business and provides a corrective mechanism in the system so that the change needs of information are with effectively. [12]

MIS has been understood and described in a number of ways. It is also popularly known as the Information System, the Information and Decision System, the Computer-based Information System. The MIS has more than one definition, some of which are given below:

1. The MIS is defined as a system which provides information support for decision making in the organization.

2. The MIS is defined as an integrated system of man and machine for providing the information to support the operations, the management and the decision making function in the organization.

3. The MIS is defined as a system based on the database of the organization evolved for the purpose of providing information to the people in the organization.

4. The MIS is defined as a Computer based Information System.

Thought there are a number of definitions, all of them converge on one single point, i.e., the MIS is a system to support the decision making function in the organization. [12]

The MIS is defined as an integrated system of man and machine for providing the information to support the operations, the management, and the decision-making function in the organization. The above definition emphasizes an association between MIS and decision-making. Application software that processes data, which is not used for decision-making, cannot be called an MIS. For instance, a computer-aided design system is not an MIS. An MIS deals with information that is systematically and routinely collected in accordance with a welldefined set of rules. In other words, data collection is a planned activity for which resources are allocated and rules are defined [8].

Gorry and Scott Morton have identified the information requirements which are present is Table 1:
Table 1: Information requirements of various levels of Management

\begin{tabular}{|l|l|l|l|}
\hline Characteristics & $\begin{array}{l}\text { Operational } \\
\text { control }\end{array}$ & $\begin{array}{l}\text { Managem } \\
\text { ent } \\
\text { control }\end{array}$ & $\begin{array}{l}\text { Strategic } \\
\text { planning }\end{array}$ \\
\hline Source & $\begin{array}{l}\text { Largely } \\
\text { Internal }\end{array}$ & $\longrightarrow$ & External \\
\hline Scope & $\begin{array}{l}\text { Well defined, } \\
\text { narrow }\end{array}$ & $\longrightarrow$ & Very wide \\
\hline $\begin{array}{l}\text { Level of } \\
\text { aggregation }\end{array}$ & Detailed & $\longrightarrow$ & Aggregate \\
\hline Time horizon & Historical & $\longrightarrow$ & Future \\
\hline Currency & $\begin{array}{l}\text { Highly } \\
\text { current }\end{array}$ & & Quite old \\
\hline Required \\
accuracy & High & $\longrightarrow$ & Low \\
\hline Frequency of use & $\begin{array}{l}\text { Very } \\
\text { frequent }\end{array}$ & & Infrequent \\
\cline { 3 - 4 } & & &
\end{tabular}

\section{OVERVIEW OF ORGANIZATION}

Birla Corporation Limited has number of plants, out of which, two at Satna (M.P.) - Satna Cement Works \& Birla Vikas Cement, Chanderia (Rajastan) - Birla Cement Works \& Chanderia Cement Works, and Durgapur (W.B) - Durgapur Cement Works \& Durga Hitech Cement and one at Raebareli (U.P). They manufacture varieties of cement like Ordinary Portland Cement (OPC), 43 \& 53 grades, Portland Pozzolana Cement (PPC), Fly Ash - based PPC, Low Alkali Portland Cement, Portland Slag Cement, Low Heat Cement and Sulphate Resistant Cement. The total employees in the plant are found around 5200 of various categories. The system developed is used to maintain attendance record for the same. [1]

\section{DEVELOPMENT OF MIS}

The development process of MIS relates with the long-term business plans of the organizations. MIS requires resources like capital, time and capacity. The end result is information in the form of reports. Most of the organizations do not recognize information as a resource. They see information as a routine necessity. As an organization grows, the information also increases manifold. The MIS plans are developed concurrent to the business plans. An organization of any size deals with numerous pieces of information. [7] 
Management Information System (MIS) may be developed using following ways:

1. Prototype method

2. Life cycle approach

In the prototype method, initial methods are developed first. Once implemented, the system is refined and modified as per The following chart shows how MIS can be developed in an organization.

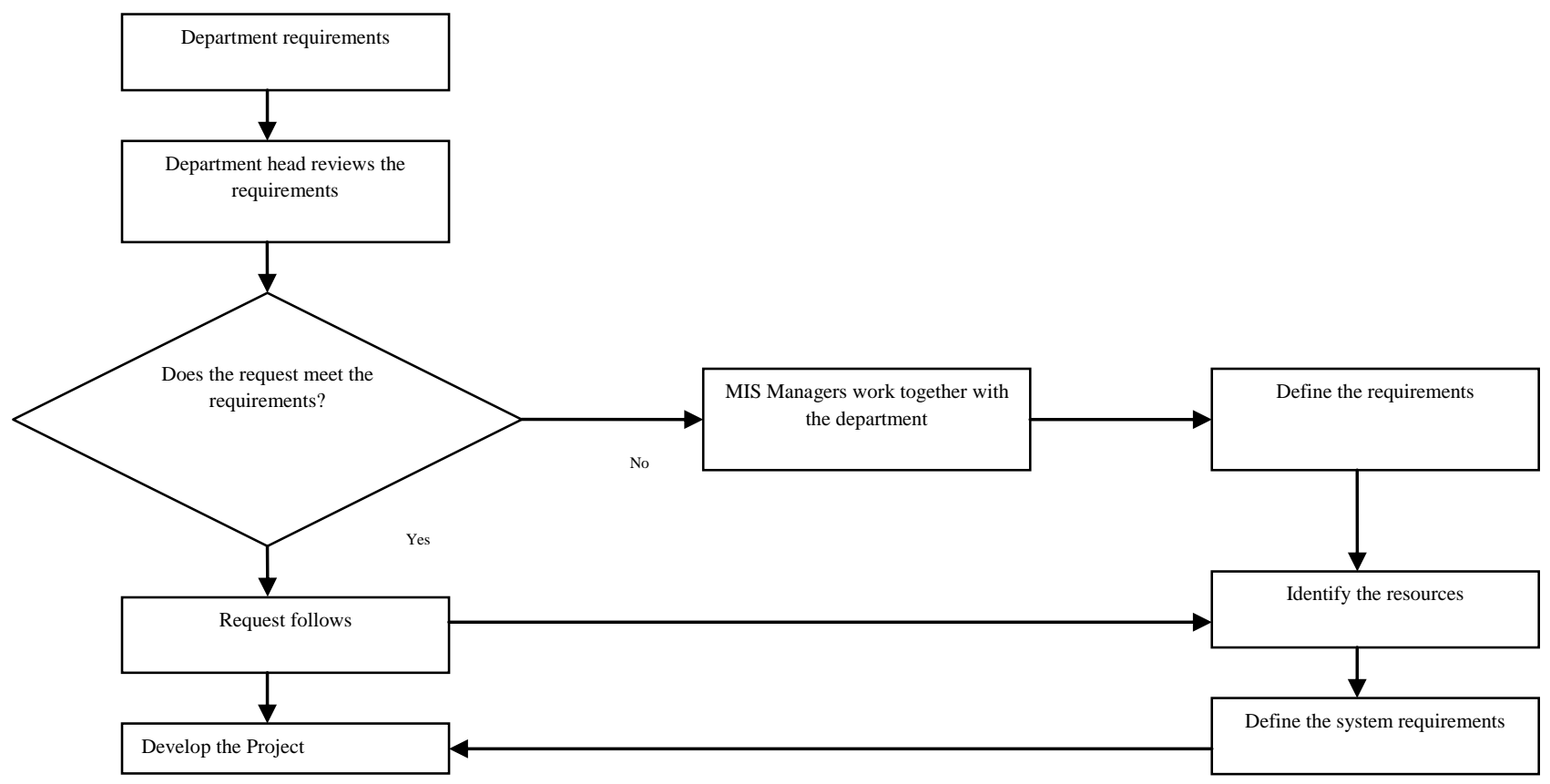

Fig. 2: Management Information System (MIS) development model

\section{DESIGNING MIS FOR ACRS}

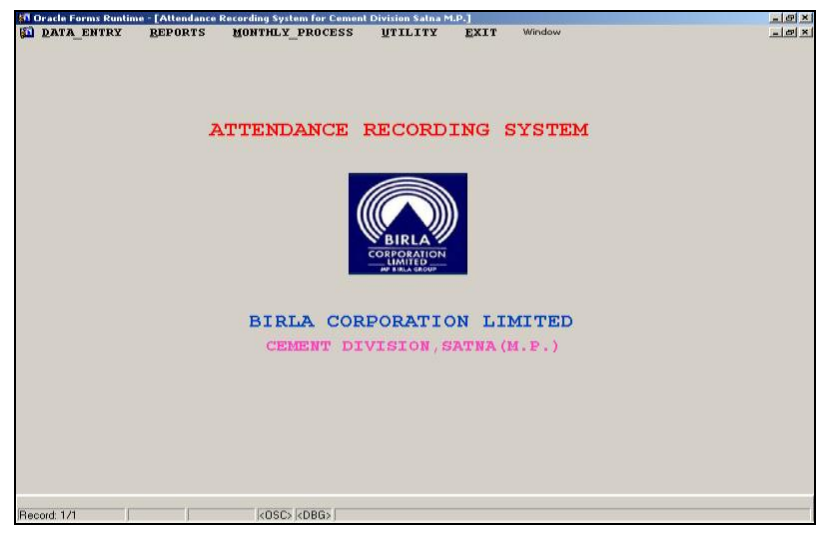

Fig. 3: MIS designed for Attendance Capturing \& Recording System

The main objective of Attendance Capturing \& Recording System (ACRS) is to ensure that the attendance (i.e. presence or absence) of employees is accurately recorded and reported for new specifications. This iterative process is followed till the system is accepted by the user. In life cycle approach, the MIS development is carried out through different phases. The phases are: Feasibility study, Analysis, Design, Implementation and Review. The choice of MIS design is decided on the basis of nature of the system and its applications. Thus the MIS is developed over time as the business increases. 
1. Establish an efficient workflow process for attendance authorization.

2. Integrate time and leave data with HR, payroll and ERP systems or to APIs for electronic processing.

3. Ensure accurate and consistent implementation of pay and leave policies.

4. Quickly and simply request leave or other scheduled absences.

5. Receive automatic notification of leave balances, as well as available vacation and personal time, sick days and other leave benefits.

The proposed system has several advantages like worker's individual information is stored separately, searching of particular information became faster, Generation of various reports made review process easy, facilities of full database backup and central control of user, well-defined authorization and security levels etc.

\subsection{Decision Making at Top Level}

A decision is basically resource allocation process that is irreversible except that a fresh decision may reverse it or it may overrule the earlier one. A decision is a reasoned choice among alternatives. The decision maker having authority over the resources being allocated makes a decision. The decision can be of various types like simple decision in which there is only one decision is to be made with many alternatives, decision may be goal oriented; decision may be strategic or tactical. The decision capacity involves intelligence, design, choice and implementation of decision maker.

The MIS designed in the study for Attendance Capturing \& Recording for Birla Corporation Limited mainly generates the reports like Daily Attendance, Monthly Attendance and Sick Report etc. on which the top management by receiving these reports analyses and the decisions regarding shifting the priority of the job, observing the performance and corrective measures are taken.

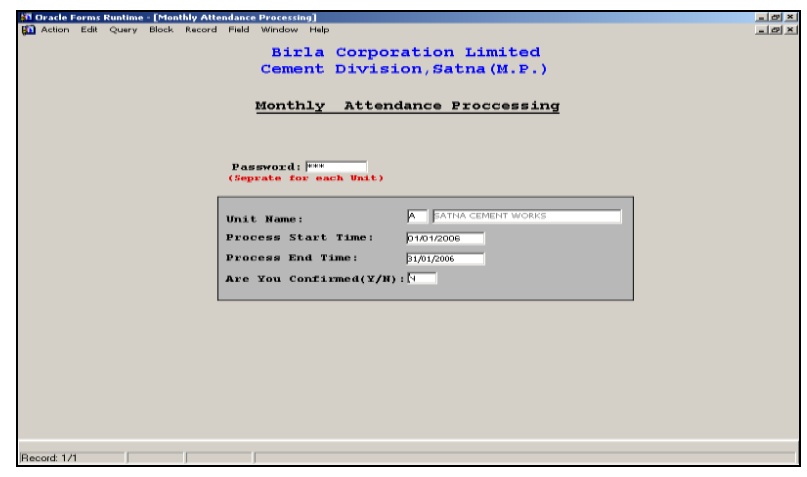

Fig. 4: Monthly Attendance Processing Form

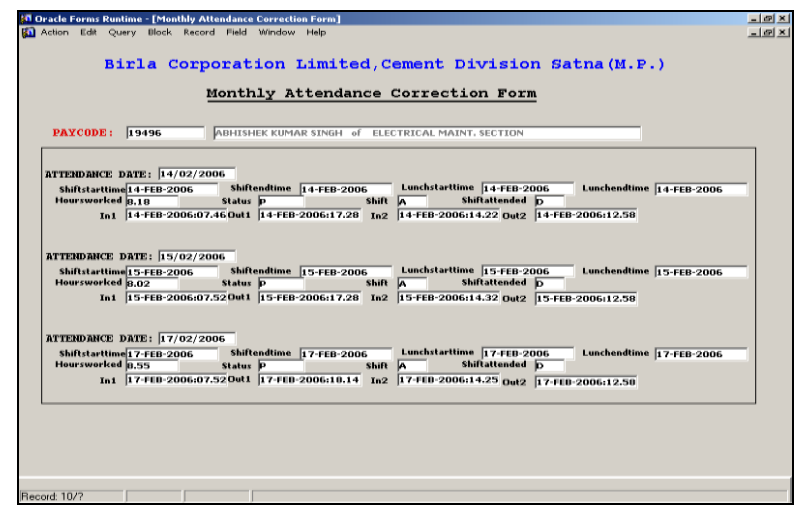

Fig. 5: Monthly Attendance Correction Form

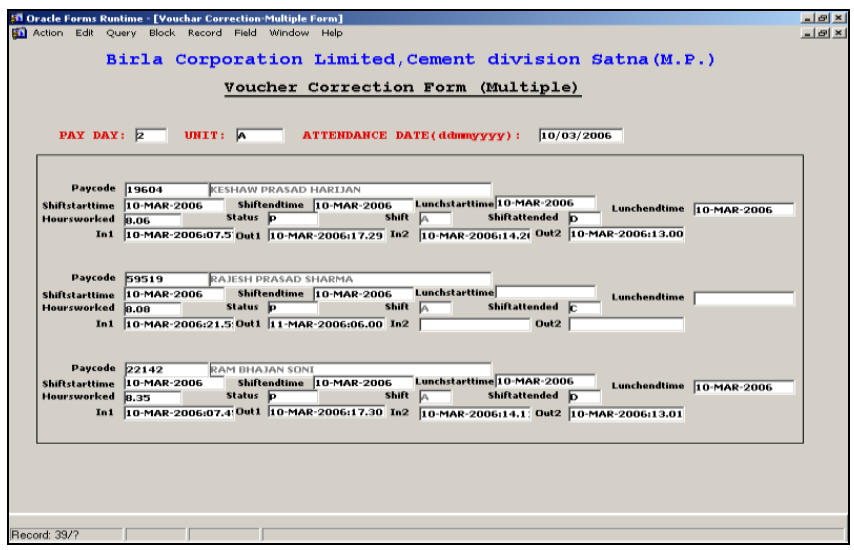

Fig. 6: Voucher Correction Form

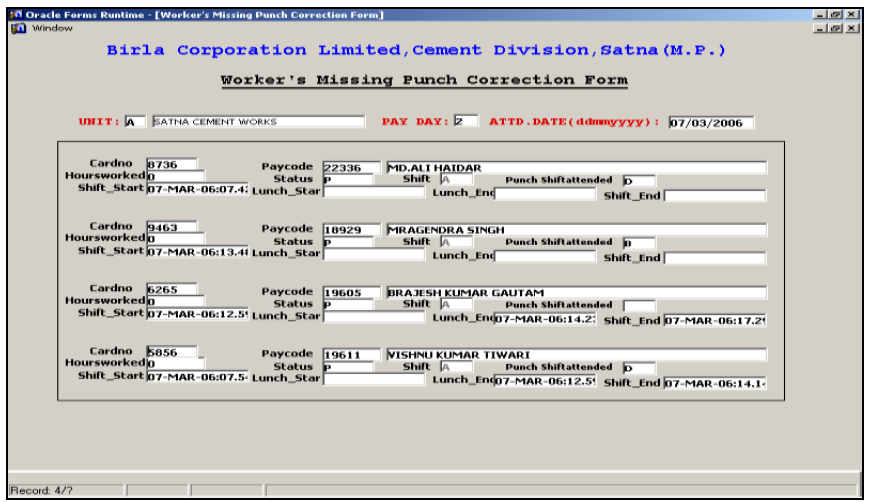

Fig. 7: Worker's Missing Punch Correction Form

\subsection{Reporting from the Designed MIS}

The reports which are used by top management are generated from the above MIS like Monthly Attendance, Card Replacement, Sick Report, and Monthly Voucher Correction which are submitted to HR Manager and he takes proper decisions related with Attendance Capturing \& Recording. 


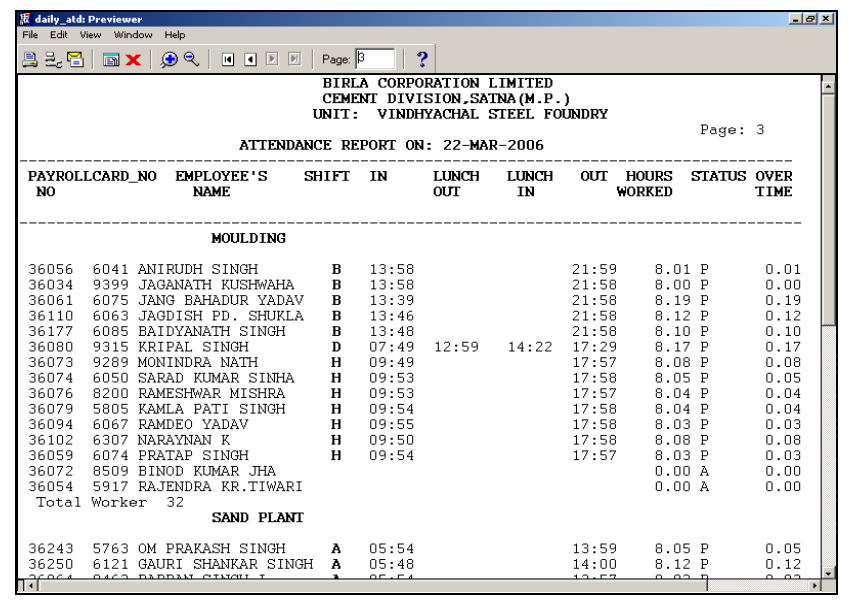

Fig. 8: Daily Attendance Report

\section{CONCLUSION}

The paper entitled 'A Study of Information Systems in Human Resource Management' gives an impact on the important function of top management. It is also used to generate the reports with the help of advanced technology having maximum characteristics of good information by which the decisions are to be taken related with the functionality of management decisions. The MIS model developed specifically helps HR managers to keep the control on working of the staff at various levels.

The system has been tested for above module in Birla Corporation Ltd. The Reports generated are as per the format by which it will help top management to take decision concerned with human resource in attendance recording and capturing which is one of the basic needs of any organization.

\section{ACKNOWLEDGMENT}

The author acknowledges gratitude to Birla Corporation Limited for providing the support for this study without their cooperation it is difficult to develop the MIS model.

\section{REFERENCES}

[1] Annual Report of Birla Corporation Limited.

[2] Arora A., Management Information Systems, Himalaya Publishing House, Mumbai.
[3] Banerjee, U. K., \& Sachdeva, R. K. (1995). Management Information System: A new frame work. New Delhi: Vikas Publishing House.

[4] Davis, G.B., \& Olson, M. H. (1985). Management information systems: Conceptual foundations, structure, and development. New York: McGraw-Hill.

[5] Dr. Milind Oka (2009), Management Information Systems Text and Cases (16 ${ }^{\text {th }}$ ed.), Everest Publishing House, Pune.

[6] Gupta R. C., Management Information Systems, CBS Publishers \& Distributers, New Delhi.

[7] Jawadekar, W. S. 1998, Management Information System, Tata McGraw Hill Publishing Company Ltd. New Delhi.

[8] Lordon K. L., Management Information System, Prentice Hall of India, New Delhi.

[9] Lucas, H. C., Jr. (1990), Information systems concepts for management. New York: McGraw-Hill.

[10] McLeod, R., Jr. (1995). Management information systems: A study of computer-based information systems (6th ed.). New Delhi: Prentice Hall of India.

[11] Murthy C. S. V., Management Information Systems, Himalaya Publishing House, Mumbai.

[12] Waman S Jawadekar (2007), Management Information Systems Text and Cases ( ${ }^{\text {rd }}$ ed.), Tata McGraw Hill Publishing Company Ltd., New Delhi.

\section{AUTHORS BIOGRAPHY}

K P Tripathi received his M.C.A., degree from Shivaji University, Kolhapur in June 2006 and M.B.A. degree from YCMOU, Nashik in Feb. 2010. He is working as Assistant Professor in M.C.A. Department, Bharati Vidyapeeth Deemed University Institute of Management, Kolhapur, India. He has presented 6 papers in National Conferences and 5 papers in International Conferences. He has published 10 papers in International Journals and 1 in National Journal. He is member of IACSIT, ICEIT and CSI. His areas of interest include Information Technology, Computer Organization \& Architecture, and Mobile Communication. 